\title{
Women's Economic Empowerment and Social Change from a Culture-Psychological Perspective
}

\author{
Silke Schwarz ${ }^{1}$ \\ ${ }^{1}$ Freie Universität Berlin, Germany \\ Correspondence: Silke Schwarz, Freie Universität Berlin, Germany. E-mail: silke.schwarz@fu-berlin.de
}

Received: September 14, 2014

Accepted: October 25, 2014

Online Published: October 30, 2014

doi:10.5430/bmr.v3n4p1

URL: http://dx.doi.org/10.5430/bmr.v3n4p1

\begin{abstract}
Since the beginning of the 1990ies, gender mainstreaming and related women`s economic empowerment programs became an integral part of development programs and global disaster management. Gender-or more generally speaking social-justice is defined as its end goal, that is a condition in which diverse needs and interests are acknowledged and shared power relations are existent. Albeit the goal of social justice appears to be clear, subjective ideals may be diverse and contradictory, depending on personal stances, religious affiliations as well as on sociocultural contexts. How do theoretical approaches developed in western countries aid analysis of, and development of interventions for social problems within non-western contexts? In this article, I address this question by investigating which gender relations are endorsed by a disaster-stricken village community in Southeast Asia. The community helps to clarify what is possible when a group of several Non-Government Organizations (NGOs) works together on issues of social justice and gender issues using livelihood programs and micro-credit schemes. On the background of the empirical findings, I discuss shortcomings of western approaches.
\end{abstract}

Keywords: Economic empowerment, Social change, Cultural psychology, Micro-credits, Disaster management, Gender, Indonesia

\section{Introduction}

\subsection{Locating Economic Empowerment and Social Change in Disaster Contexts}

Disasters and ensuing aid flows can help change the social fabric and power relations. Crisis-ridden economic, political and cultural processes as well as shifts in the gender relations and identities are likely to accompany the exceptional event of a disaster and subsequent flows of assistance.

The field of disaster research and management is dominated by universalist approaches (Hewitt, 2012). In other words, most approaches are developed in high-income countries from the Global North to be applied anywhere else, including middle- or low-income countries in the Global South (Note 1). The aid business itself has increasingly been questioned as a means of political manipulation to pursue specific, mostly western agendas in the name of humanitarian efforts. In response to criticisms such as these, guidelines and frameworks were formulated to establish standards for disaster aid (ALNAP, 2008). Following the basic principle of "do no harm" (Anderson, 1999), these documents call for the avoidance or reduction of aid-related social conflict. However, conflict potential often increases when actors follow additional hidden or overt agendas while providing aid, an observation that has been noted with regard to some gender mainstreaming and civil rights approaches (see ALNAP, 2008).

On the one hand, gender justice is defined as the ultimate goal of aid-related development; on the other hand it should contribute to development and disaster risk reduction. It is a condition in which the different interests and needs of the genders are recognized and equitable power relations and fields of responsibility exist between men and women (Wichterich, 2010; Ariyabandu \& Wickramasinghe, 2005; DAWN; Duryog Nivaran (Note 2); Schwarz, 2014a; United Nations, 2000; United Nations \& International Strategy for Disaster Reduction, 2007). Although the goal of gender justice appears unequivocal in terms of its broad conceptual design and values, the question remains as to which exact direction change should take. This universalistic definition obscures possible conflicts. There can be strong differences and in some cases even contradictions about what is perceived as fair or desirable. For some, justice can mean to have the same roles and duties in daily lives, for others it can encompass to take on different, that is usually complementary roles. When attempting to be socioculturally sensitive and critical of power relations, it is 
essential to consider these aspects (Anderson, 1999, 2000, 2004).

The possibilities for social change moving towards more just ways of living after disasters have been studied in various sociocultural contexts (Ariyabandu, 2003; Chowdhury, 2001; Yonder, Akcar \& Gopalan, 2006; Bari, 1998). Some studies, however, describe contrary dynamics with a tendency towards retraditionalization (Bradshaw, 2001, 2002; Hoffman, 1999). Various instruments for generating and motivating social change after a disaster are common: income-generating activities (usually in the form of peer-monitored loans), awareness-rising programs as well as organizational work in the community (for example through forming micro-credit groups) (Buckland, 1998).

The following section refers to social psychological theoretical approaches developed in western countries. It introduces the common use of universalistic approaches and related challenges. Subsequently the research site and applied methods are presented in order to illustrate a culture-specific psychological research design. In the results section, I investigate gender relations that a disaster-stricken village community in Southeast Asia endorses. On the background of the empirical findings, shortcomings of mainstream social psychology theories are discussed. The key question of this paper is: how do western approaches aid analysis of, and development of interventions for social problems within non-western contexts?

\subsection{Social Change from Social Psychological Western Perspectives}

Mainstream social psychological approaches exemplify universalistic theories that are theories that claim universal applicability. Context variations such as cultural specifities are often neglected. Cultural-psychological approaches question the quest of finding universal regularities, instead shifting focus to the culturally specific. Popular and wide-spread examples for social psychological theories are the social dominance theory developed by Sidanius and Pratto (1999) and Sidanius, Pratto, van Laar and Levin (2004) as well as the system justification theory formulated by Jost and Banaji (1994) and Jost, Banaji and Nosek (2004). Both theories deal with issues of intergroup relations, and thereby transcend the individualistic focus typical of the psychological gaze, and focus on the maintenance and stability of group-based social hierarchies. A core assumption is that people have a psychological need to maintain stability and order in their lives.

The social dominance theory claims a tendency to maintain and to enlarge hierarchical differences by manifested prejudices and related discriminatory practices. This tendency is called the social dominance orientation. It is defined as an explanatory motive for the maintenance of the status quo: dominant groups (such as heterosexual White middle-class men) score higher on the social dominance orientation scale compared to members of a subordinated group (such as homosexual African low-income men). The social dominance scale encompasses two factors: group-based dominance-GBD—and general opposition to equality-OEQ (Pula, McPherson \& Parks, 2011). Examples for items of the GBD-factor are „If certain groups stayed in their place, we would have fewer problems” (ibid., p. 387) or „It is OK if some groups have more of a chance in life than others” (ibid.). Examples for items that load negatively on the OEQ-factor are „We would have fewer problems if we treated people more equally“ (ibid.) or „Group equality should be our ideal“ (ibid.).

The second theory stresses processes of accommodation and rationalization to explain an enduring status quo. The four basic theoretical assumptions are: „(a) there is a general ideological motive to justify the existing social order, (b) this motive is at least partially responsible for the internalization of inferiority among members of disadvantaged groups, (c) it is observed most readily at an implicit, nonconscious level of awareness and (d) paradoxically, it is sometimes strongest among those who are most harmed by the status quo" (Sidanius et al., 2004, p. 881).

These theories exemplify problematic aspects of universalistically designed mainstream social psychological approaches. Overall, a focus on the status quo is dominant instead of an emphasis on liberation, the tools and mechanisms for social change (Prilleltensky, 2011). In western theories, equality gains the status of a highly valued end-goal of groups and societies. It is debatable to what extent these social psychological universalistic theoretical approaches developed in western countries can aid analysis of, and development of interventions for social problems within non-western contexts. In this paper, I address this aspect by investigating which gender relations are endorsed by a disaster-stricken village community in Southeast Asia in section 3. For this purpose, research strategies that help to gain a more local, specific and contextualized picture of the situation are necessary.

\section{Contextualizing the Research Site}

Instead of looking for universal ways for women's empowerment and social change, a culture-specific approach needs to grasp locally specific meanings of events, experiences, and actions. It is essential to develop a grounded understanding of how meanings are formed in social interaction and broader discourses as well as how they change and are modified by interpretation. For contextualizing the research site, I describe the socioeconomic context, the 
disaster event as well as subsequent reconstruction efforts hereinafter. Section 2 ends with a short description of used methods.

\subsection{Socioeconomic Context}

The village examined in this case study is located in Central Java, Indonesia, a region with a long history of natural disasters. The chosen research site with its proximity to the city of Yogyakarta, Indonesia, offers more employment opportunities and markets in nearby Yogyakarta town when compared to other rural regions in Java. Most households rely on a mixed-income livelihood, combining agriculture with sand mining, construction labor, or small industries supplying larger businesses outside the village. Furthermore, many maintain small home businesses, producing, for example, noodles and biscuits from manioc, as well as ceramics. None of these livelihoods generate steady income nor do they provide access to a social security system including health insurance or pensions. Very few village residents are employed on a regular basis in factories or in the service industry of the city periphery. Even fewer work in government institutions or for the military. In general, these regular employment opportunities are particularly desirable, because they are prestigious and include social security services such as health insurance and pensions. Considered within the larger Indonesian context, national and international labor migration serves as an important source of income, often used to provide for other family members or to accumulate capital to start a business or build a house. With regards to pension, children are expected to provide for their elderly parents. For the younger generation, education is seen as a key to success. Schooling fees, however, limit access to education. Thus, it is common that, among siblings, only one child will continue schooling while the other(s) work to support her or his education.

Worldwide, the number of informal credit systems has increased over the last 30 years (Ghazali, 2003), not least because of various development and gender mainstreaming programs (Buckland, 1998). Indonesian credit schemes link with a longer history and tradition of the so-called arisan associations (Geertz, 1962). It is a form of microfinance with an emphasis on social aspects of the gathering that takes place at a fixed interval and at each member's home in turn. The rotating arisan holder (drawn by lots) receives payment from each other member and provides food. In the course of the arisan the amount paid to other members will equal the amount received when the arisan is held. From an empowerment perspective, micro-credit schemes are thought to support gender justice as women gain an own income and control over it. As a result, female bargaining position is strengthened and detachment from patriarchal control systems enhanced (Bloemen, 2010; Agarwal, 1997).

Javanese family economies were examined frequently by researchers, however resulting in contradictory assessments. Geertz (1961) and Jay (1969) portray Javanese women as independent, economically autonomous, and equal or superior to their male counterparts. Women's control over the family income was seen as an indicator of their level of autonomy, therefore suggesting the high status of Javanese women. Koentjaraningrat (1967) and Keeler (1990) instead, argue that women are neither subordinate nor superior to men, but rather have a kind of indirect influence and other forms of power. From a third perspective, inspired by a feminist branch of research, economic autonomy and patriarchal control co-exist. Even though Javanese women gain a relatively high level of agency in terms of their real economic power, this is inextricable from the formal authority of the man (Berninghausen \& Kerstan, 1984; Kerstan \& Berninghausen, 1991; Berninghausen et al., 2009; Wolf, 1992).

\subsection{Earthquake on 27 May 2006 and Reconstruction Efforts}

In the early morning of May 27, 2006 at 5.53 a.m. local time, a 6.2 magnitude earthquake hit the provinces of Yogyakarta and Central Java, Indonesia. About 300,000 houses were destroyed and another 200,000 damaged. More than 6,000 fatalities and 20,000 injuries were recorded (OCHA, 2007). A material damage of up to 3.1 billion US \$ (JRF, 2007) was registered, exceeding the financial damage estimates for the 2004 tsunami that hit Sri Lanka, India, and Thailand and comparable to those of the 2001 Gujarat, India and 2005 Pakistan earthquakes (Leitman, 2007). The damage was unusually concentrated in the housing, social, and production sectors. The disaster had a significant socioeconomic impact, affecting living conditions and workers' revenues in small and medium enterprises. Households and private companies without any insurance coverage were particularly affected by the disaster (Subagyo \& Irawan, 2008).

Many organizations were involved in the post-earthquake emergency and reconstruction process, including UN agencies, as well as international and national NGOs (Wilson \& Reilly, 2007). Implementing a lesson-learned from the 2004 Aceh tsunami aid experience, a cluster approach was pursued to coordinate humanitarian relief efforts, an approach which later became a model for more effective humanitarian response (WHO, 2007). The efforts were divided into thematic clusters or sections. The clusters were defined in accordance with corresponding UN agencies and included water and sanitation, livelihood, food, agriculture, education, health and shelter (MacRae, 2008). 
Several livelihood programs aimed to increase gender justice. Kabeer's (1994) distinction between gender-neutral, gender-specific and redistributive political action is often used in order to assess the distribution of resources between men and women. Only a redistributive policy will allow sustainable and far-reaching transformation of existing gender relations, enabling more just forms of living.

The case study with its cultural specifities of Javanese family economics will help to exemplify the limits of universalistic approaches that are common in social psychology. The investigation of the Javanese village community Sido Kabul (Note 3) struck by the earthquake can clarify what is possible when a group of several Non-Government Organizations (NGOs) works together on issues of social justice and gender. Most institutions were organized in a network with funding provided by the Ford Foundation. An Indonesian institution acted as the on-site intermediary organization, all NGO workers were Indonesian citizens. The program began twelve months after the earthquake, and was scheduled to run for one year. One NGO provided information about gender equity, educated female villagers about violence against women, and promoted women's reproductive health and children's health. A communal domestic violence group was formed. Other organizations offered small loans to village women, at first exclusively for female entrepreneurs, but extended later to a wider circle of women. Besides the financial support, business-related training was available. The target group of all these programs was exclusively women, most of whom were married. As part of the extensive reconstruction efforts, a hamlet development committee was founded-consisting exclusively of men - as well as a cattle breeding group which was used to carry out educational work on the subject of civic rights. This group was also directed primarily at men.

\subsection{Methods}

The views of both male as well as female villagers and activists (that is the staff of the above described NGOs) will be reconstructed in this paper (Note 4). The villagers' sample encompasses more than 23 persons with variations in several dimensions: age (average age 36,5 years with the youngest participant of 22 years and the oldest one of 52 years), education (bachelor degree being the highest educational degree and primary school the lowest), occupation (unemployee until governmental employee), number and age of children (none until nine children), social position within communal power structures (official group leader until less influential and respected persons), and membership in NGO (no membership at all until membership in several NGO groups). For data collection, qualitative interviews (narrative and guideline-supported interviews), focus group discussions and participant observations were applied. Using Situational Analysis (Clarke, 2005), I developed a heuristic framework for social change in the contested field of gender justice.

Critical lines of thought as developed in feminist theories were helpful tools to balance out the above mentioned shortcomings of mainstream social psychological theories. I used postcolonial and deconstructivist feminist theories to gain a perspective on gender that is historical and critical of power relations. A thorough discursive analysis of the existing anthropological literature on Indonesian gender relations helped to contextualize the study (for details see Schwarz, 2014a). In this paper, I understand gender as a sociocultural construct. It describes a social practice, characterizes social roles and is anchored in social structures. It is thereby apparent in social interactions and is reflected in political and economic dimensions of life. Ultimately, it is also written into the mental state of people as a multitude of internalized discursive positions. Gender relations are produced both through discourse and through social interactions, as well as being structured by these in turn (Lorber \& Farrell, 1991; Errington, 1990; Narayan \& Harding, 2000; Bourdieu, 2005; Mae \& Saal, 2007; Hermans \& Hermans-Konopka, 2010).

In the next section, I discuss shortcomings of mainstream social psychology theories on the background of the empirical findings. Which gender relations does a disaster-stricken village community endorse? How do these Central Javanese ideas relate to western moral calls for equality? Furthermore, I elaborate on economic roles, responsibilities and duties. Which kinds of influence and decision-making powers are attributed to women and men? The productive role is associated with power structures, as it is accompanied by access to and control over certain resources, whether social networks, information or financial resources (see also Agarwal's, 1997, concept of the bargaining position).

\section{Results and Discussion: Local and Western Understandings of Gender Justice}

What kind of gender relations does a village community endorse after a disaster and the implementation of various gender mainstreaming programs, that is mainly micro-credits and awareness-rising programs? At a basic level, almost all interviewees agreed that desirable and equitable gender relations were characterized by treating one another respectfully: "it's about respecting and appreciating one another as husband and wife" as a villager put it.

However, there are various, sometimes contradictory ideas and feelings about how treating one another respectfully 
is put into practice. Some men and women expressed a preference for clearly separated areas of responsibility, which I refer to as complementary orientation or complementarity. Interviewees presented these tasks as equitable and, on this view, men and women should complete one another, compensating for each other's "shortcomings" and reinforcing one another when solving problems. Other study participants described an equal distribution of tasks as being desirable. They tended not to assign men and women roles, abilities, rights or obligations on biological grounds. Within family life, this means that both men and women should complete household chores and be responsible for childcare. Both should play a productive role through paid work. Villagers with this egalitarian attitude sanctioned political leadership and participation by women and men alike. NGO workers who were interviewed consistently subscribed to this egalitarian line of thought. The awareness-rising work initiated by them has focused in particular on promoting an understanding of egalitarian goals. They introduced and fortified concepts of gender, gender justice, gender equity and gender equality as a public discourse in the village. These terms have become increasingly popular and common.

The shared norm of respectful cooperation represents a common and basic value when faced with the almost contradictory positions of egalitarianism and complementarity. In both cases, a recognition and acceptance of the other person, with his or her "shortcomings", was aspired to. Furthermore, the equal worth of both genders is emphasized despite certain differences. Gender justice is equated with harmony and togetherness-that are highly valued cultural goods. The values of harmony and togetherness imply cooperative actions; that is, having a common goal and shared interests and responsibilities, a willingness to work together, and actually working together to achieve this goal. As a culture-specific rule, overt expressions and conflicts should be avoided (Mulder, 1983; Magnis-Suseno, 1989). Containing public conflicts should not be mistaken for an absence of conflict, however. People may find more indirect and subversive ways of expressing their disagreement or protest (Schweizer, 1989; Schwarz, 2014b, 2014c). Referring to a collectively shared benchmark, the basic ideal of treating one another respectfully, probably helped to avoid open conflict. Instead of insisting on western ideas such as the rights of women, locally specific symbolism was expanded to create greater acceptance rather than resistance about women's roles being equal to those of men in Java. Berninghausen, Kerstan and Soeprapto-Jansen (2009) describe similar dynamics of "western" and "eastern" concepts: "We are seeing that in Indonesia, old and new values do not need to be seen as being in contrast to one another, nor need the old values be uncritically replaced by the new. The conflicting values and role requirements do not supersede each other, but rather continue to exist side by side. Instead of the confrontational "either...or..." attitude typical of Germany, the conciliatory Asian "both...and..." can be found in Indonesia" (ibid., p. 81) (Note 5).

When transferring the discursive level to everyday practices, the picture becomes even more ambiguous. Regardless real family income structures and regardless whether complementary or egalitarian gender relations are endorsed, all villagers regard women as supplementary earners two to four years after the NGO programs. This discursive stance defines men as main breadwinners, irrespective of the real income levels of women and men. With regard to managing the family's finances, it is usually the woman who takes a leading role. Even in family businesses, large or small, it was the woman who assumed responsibility for both domestic financial management and keeping the business accounts. This is justified by the argument that man would have a natural tendency to be wasteful and hedonistic, while a woman could be economical and thrifty, and would be better able to keep an eye on the family's various financial obligations. Interviewees of both genders produced these stereotypical gendered accounts, regardless of whether they otherwise presented themselves as adopting an egalitarian or complementary stance of the division of labor in households. Both men and women presented the male "shortcoming" as a matter of common knowledge and not as being objectionable or shameful in any way. However, the female obligation to budget well with the existing and often scant finances, while considering the needs of all family members as well as communal obligations can also become a burden. Several women complained that they felt left alone to deal with financial problems. In this respect, the female financial management and its implications for the gendered power relations on Java is contradictory.

According to the villagers, female employment can lead women to gain more courage and confidence as they make a meaningful contribution to the family and village economy, thereby earning recognition, respect and support from their husbands and other men in the hamlet. The employment of women was also seen as increasing the likelihood that men would become involved in the household chores and childcare. Critical gender awareness on the part of men and their willingness to play a supportive role however stays crucial, according to the villagers. Even though, in Sido Kabul, women`s economic empowerment has increased the public presence of women in the community, this has not led them to gain any political decision-making power in the hamlet. In addition, adverse effects of female employment and the micro-credits were stated, such as multiple burdens, a lack of time for other activities or 
financial burdens (such as marketing problems, or the potential to fall into debt traps).

The role of the financial manager does not necessarily equate with that of the decision-maker. Most research participants either favored a shared decision about internal family affairs as the ideal practice or the man was put as the ultimate decision-maker. Others emphasized the illusory character of this discursive presentation: the woman only formally respects her husband in his social role as head of the family and in order to uphold this pretense, she would ask him for permission if she wants to order cassava, for example. And still, regardless ideological preferences and real family income structures, all villagers emphasized that the man remains in the role of head of the family. He was consistently declared as having the main responsibility for the family economics, and the woman was identified as a supplementary earner and financial manager. The masculine role assignment as the one in paid employment and main earner needs no further legitimation. Indeed, a man had to justify being unemployed, whilst female employment necessitated an explanation such as economic necessity, a new consciousness or awareness of gender justice or that employment was simply facilitated by access to capital through the NGOs and their small loans.

How do these local understandings and practices of gender relations relate to western ideas? According to system justification theory, complementary ideals stabilize the existing system instead of challenging it. Furthermore, the key assumption is that the existing system is based on inequality and that inequality is always and by all experienced as unjust and therefore needs to be changed. System justification theory argues that those villagers, that endorse complementary ideals and practices, are affected by distorted perceptions. They would accept inequality (and therefore also injustice) because of the universal human motive to live in a just world, that is they want to sustain a feeling of trust, hope and confidence. A complementary gender rhetoric, which is common in Islamic feminist movements, is equated with benevolent sexism (Glick \& Fiske, 1996) and thereby also devalued per se. In universalistic social psychological thinking, complementarity cannot be understood without difference and hierarchy. This assumption is very problematic for most Asian cultural contexts as the anthropologist Robinson (2009) explains: „Dyadic oppositions of male/female, wife-giver/wife-taker, inner/outer, north/south, older/younger or trunk/tip are common, but they cannot be lined up in columns that indicate a fixed hierarchy or order of precedence between them. [...] And while the term female is commonly associated with inner/still and male with outer/active, such terms can be reversed ('categorial reversal') and the term inner/still, for example, can be superior. Using analytical principles, it is difficult to argue for a hierarchical ordering of the pair 'male-female' at the level of symbolism which can be read back as an expression of male dominance“ (ibid., p. 19).

Similarly, social dominance theory understands equality as free of hierarchies and dominance and constructs complementary as its counterpart. Thus, complementarity is automatically characterized by hierarchy and dominance. Equality becomes the morally and ethically ideal-universally for all societies and at all times. Other standpoints, such as Islamic feminist approaches that value complementary roles free from hierarchies, become discrepancies from the normatively "right" goal. This entails the danger of a moral western imperialism. In order to avoid this, current feminist theory developments and anthropological literature must enhance psychological mainstream theories and practices. For example, a Muslim female villager claimed that household and child care are mainly female tasks, while generating family income is mainly a male task. However, also women could support the family income, and also men should take an active role in children's education. She valued both tasks as equitable in a non-hierarchical manner. And even though she called her husband the head of the family, she describes egalitarian family decision practices. Furthermore, she favored for political participation of women. Applying social psychological theories, these contradictions and subversive strategies would not become visible.

Reference to existing, locally specific values about which there is a consensus, such as the ideal of respectful cooperation between men and women (symbolizing the Javanese "both...and..."- principle) can simultaneously act both in an empowering and a restrictive way. Time will tell where the interplay between holding onto existing structures and simultaneously introducing innovation will lead. For example, it appears to be increasingly acceptable in public that women play a productive role comparable to that of men, whilst at the same time the discourse of the main bread-winner being a masculine role is vehemently maintained. These (ambiguous) achievements were driven by Javanese activists who are familiar with Javanese symbolism and how to use it.

\section{Conclusion}

A transdisciplinarity between sociology/gender studies, anthropology and psychology can account for cultural specifities instead of assuming universal patterns per se. A thorough consideration of relevant anthropological research contributes to a higher awareness for cultural specifities. Postcolonial thinking and a deconstructivist standpoint support a focus on local specifics and account for historically produced, global power differentials instead of generalizing theories or concepts developed in the North to the behavior of people in the South. This hybrid and 
critical perspective accounts for locally specific power differentials that are historically rooted and globally intertwined. These anthropological and sociological gazes substantially enrich mainstream psychological approaches. This paper tried to illustrate the shortcomings of social psychological approaches on the background of a culture-psychological study and pointed to the danger of a moral western imperialism. Similarly, Hudnall and Lindner (2006) caution against trying to impose western ideas upon stakeholders worldwide: "It is important to remember that white middle-class women from the economic North have dominated the feminist movements. Moreover, many aid workers and the people creating treatment plans and policies for humanitarian operations also represent the goals and ideals of privileged western societies, so that most of the tactics and strategies employed by humanitarian psychosocial staff are informed from this world view" (ibid., p. 13).

The main challenge for culture-specific approaches lies in the difficulty of transferring research results to other contexts. Within a cultural-specific theoretical framework, the research interest encompasses people's culture-specific - rather than universally applicable—understandings of gender, economic practices as well as related power relations, and relevance and meaning they ascribe to it. The analytic focus was on everyday and related discursive practices in their particular cultural settings. As a result, the main objects of study were not technical features, social structures, organizational forms, or institutional and political processes after a disaster and related livelihood programs. In a transdisciplinary gender psychology however, these issues are contexts of interest, since research participants refer to these contexts.

\section{References}

Active Learning Network for Humanitarian Practice (ALNAP) (2008). Responding to earthquakes 2008: Learning from earthquake relief and recovery operations. London: ALNAP. http://www.alnap.org/publications/pdfs/ALNAPLessonsEarthquakes.pdf. Accessed 29.03.2014.

Agarwal, B. (1997). Bargaining and gender relations. Within and beyond the household. Feminist Economics, 3(1), 1-51. . http://dx.doi.org/10.1080/135457097338799

Anderson, M. B (1999). Do no harm: How aid can support peace or war. Colorado: Lyenne Rienner Publishers.

Anderson, M. B. (Ed.). (2000). Options for aid in conflict. Lessons from field experience. Cambridge: The Collaborative for Development Action. http://www.cdainc.com/publications/dnh/options/OptionsManual.pdf. Accessed 29 .03.2014.

Anderson, M. B. (2004). Experiences with impact assessment: Can we know what good we do? Berghoff Forschungszentrum für konstruktive Konfliktbearbeitung. http://www.berghof-handbook.net/uploads/download/anderson_handbook.pdf. Accessed 29.03.2014.

Ariyabandu, M. (2003). Women: The risk managers in natural disasters. http://www.ssri.hawaii.edu/research/GDWwebsite/pdf/Ariyabandu.pdf. Accessed 10.05.2013.

Ariyabandu, M., Wickramasinghe, M. (2005). Gender dimensions in disaster management. A guide for South Asia. Kirulapone, Sri Lanka: ITDG South Asia.

Bari, F. (1998). Gender, disaster, and empowerment: A case study from Pakistan. In E. Enarson, B. H. Morrow (Eds.), The gendered terrain of disaster - through women's eyes (pp. 125-131). London: Praeger.

Berninghausen, J., \& Kerstan, B. (1984). Die Töchter Kartinis. Berichte und Reportagen aus dem Leben indonesischer Frauen. Berlin: Express Edition.

Berninghausen, J., Kerstan, B., \& Soeprapto-Jansen, N. (2009). Schleier, Sarong, Minirock. Frauen im kulturellen Wandel Indonesiens. Bremen: Kellner-Verlag.

Bloemen, H. (2010). An empirical model of collective household labour supply with non-participation. The Economic Journal, 120(543), 183-214. http://www.blackwell-synergy.com/doi/abs/10.1111/j.1468-0297.2009.02292.x

Bourdieu, P. (2005). Die männliche Herrschaft. Frankfurt/Main: Suhrkamp.

Bradshaw, S. (2001). Reconstructing roles and relations: Women's participation in reconstruction in post-Mitch Nicaragua. Gender and Development, 9(3), 79-87. http://dx.doi.org/10.1080/13552070127757

Bradshaw, S. (2002). Exploring the gender dimensions of reconstruction processes in post-hurricane Mitch. Journal of International Development, 14(6), 871-879.

Buckland, J. (1998). Social capital and sustainability of NGO intermediated development projects in Bangladesh. 
Community Development Journal, 33(3), 236-248. http://dx.doi.org/10.1093/cdj/33.3.236

Chowdhury, M. (2001). Women's technological innovations and adaptions for disaster mitigation: A case study of charlands in Bangladesh. Paper presented at expert group meeting on ,Environmental management and the mitigation of natural disasters: A gender perspective'. Ankara: United Nations Division for the Advancement of Women (DAW) \& International Strategy for Disaster Risk Reduction (ISDR).

Clarke, A. (2005). Situational analysis. Grounded Theory after the postmodern turn. Thousand Oaks, CA: Sage Publications.

Errington, S. (1990). Recasting sex, gender, and power. In J. M. Atkinson, \& S. Errington (Eds.), Power and difference. Gender in island Southeast Asia (pp. 1-58). Stanford: Stanford University Press.

Geertz, C. (1962). The rotating credit association: A "middle rung" in development. Economic Development and Cultural Change, 10(3), 241-263. http://dx.doi.org/10.1086/449960

Geertz, H. (1961). The Javanese family: A study of kinship and socialization. New York: Free Press of Glencoe.

Ghazali, S. (2003). Kut (informal rotating credit) in the livelihood strategies of urban households in Penang, Malaysia. Area, 35(2), 183-194. http://dx.doi.org/10.1111/1475-4762.t01-2-00106

Glick, P.; Fiske, S. T. (1996). The ambivalent sexism inventory: Differentiating hostile and benevolent sexism. Journal of Personality and Social Psychology, $70 \quad$ (3), pp. 491-512. http://dx.doi.org/10.1037/0022-3514.70.3.491

Hermanns, H., \& Hermanns-Konopka, A. (2010). Dialogical self theory: Positioning and counter-positioning in a globalizing society. Cambridge: Cambridge University Press. http://dx.doi.org/10.1017/CBO9780511712142

Hewitt, K. (2012). Culture, hazard and disaster. In B. Wisner, J. C. Gaillard, \& I. Kelman (Eds.), Handbook of hazards and disaster risk reduction (pp. 85-108). New York: Routledge.

Hoffman, S. (1999). The regenesis of traditional gender patterns in the wake of disaster. In A. Oliver-Smith, S. Hoffman (Eds.), The angry earth: Disaster in anthropological perspective (pp. 173-191). New York: Routledge.

Hudnall, A. C., \& Lindner, E. G. (2006). Crisis and gender: Addressing the psychosocial needs of women in international disasters. In G. Reyes, \& G. A. Jacobs (Eds.), Handbook of international disaster psychology (pp. 1-18). Westport: Greenwood Publishers.

Java Reconstruction Fund (JRF) (2007). One year after the Java Earthquake and Tsunami: Reconstruction Achievements and the Results of the Java Reconstruction Fund. http://siteresources.worldbank.org/INTINDONESIA/Resources/226271-1168333550999/ReportJRF.pdf. Accessed 4 Feb 2010.

Jay, R. R. (1969). Javanese villagers. Social relations in rural Modjokuto. Cambridge: MIT Press.

Jost, J. T.; Banaji, M. R. (1994). The role of stereotyping in system-justification and the production of false consciousness. British Journal of Social Psychology, 33 (1), pp. 1-27. http://dx.doi.org/10.1111/j.2044-8309.1994.tb01008.x

Jost, J. T.; Banaji, M. R.; Nosek, B. A. (2004). A decade of system justification theory: Accumulated evidence of conscious and unconscious bolstering of the status quo. Political Psychology, 25 (6), pp. 881-919. http://dx.doi.org/10.1111/j.1467-9221.2004.00402.x

Kabeer, N. (1994). Reversed realities. Gender hierarchies in development thought. London: Zed Books.

Keeler, W. (1990). Speaking of gender in Java. In J. M. Atkinson, \& S. Errington (Eds.), Power and difference. Gender in island Southeast Asia (pp. 127-152). Stanford: Stanford University Press.

Kerstan, B., \& Berninghausen, J. (1991). Emanzipation wohin? Frauen und Selbsthilfe in Java, Indonesien. Kritische und selbstkritische Forschungsberichte zur Dritten Welt. Frankfurt/Main: Verlag für Interkulturelle Kommunikation.

Koentjaraningrat (1967). Tjelapar: A village in south central Java. In Koentjaraningrat (Ed.), Villages in Indonesia (pp. 244-280). Ithaca: Cornell University Press.

Leitmann, J. (2007). Cities and calamities: Learning from post-disaster response in Indonesia. Journal of Urban Health, 84(1), 144-153. http://dx.doi.org/10.1007/s11524-007-9182-6 
Lorber, J., \& Farrell, S. A. (Eds.). (1991). The social construction of gender. Newburry Park, USA: Sage.

MacRae, G. (2008). Could the system work better? Scale and local knowledge in humanitarian relief. Development in Practice, 18(2), 190-200. http://dx.doi.org/10.1080/09614520801898970

Mae, M., \& Saal, B. (2007). Einleitung. In M. Mae, \& B. Saal (Eds.), Transkulturelle Genderforschung - Ein Studienbuch zum Verhältnis von Kultur und Geschlecht (pp. 9-17). Wiesbaden: Verlag für Sozialwissenschaften.

Narayan, U., \& Harding, S. (2000). Decentering the center: Philosophy for a multicultural, postcolonial, and feminist world. Bloomington: Indiana University Press.

Office for the Coordination of Humanitarian Affairs (OCHA). (2007). Cluster approach: Lessons learned: Yogyakarta and Central Java earthquake, Indonesia. http://star-tides.net/node/2081. Accessed 8 May 2013.

Prilleltensky, I. (2011). People, places, and programs promoting justice and well-being. PsycCritiques, 56 (36). http://www.deepdyve.com/lp/psyccritiques-reg/people-places-and-programs-promoting-justice-and-well-being71Hph1dgJs. Accessed 24.03.2014.

Pula, K.; McPherson, S.; Parks, C. D. (2011). Invariance of a two-factor model of social dominance orientation across gender. Personality and Individual Differences, 52 (3), pp. 385-389. http://dx.doi.org/10.1016/j.paid.2011.10.046

Robinson, K. (2009). Gender, Islam, and democracy in Indonesia. London: Routledge.

Schwarz, S. (2014a). Gendergerechtigkeit als Universalkonzept? Kritische und kultursensible Analysen von Gendermainstreaming nach einer Katastrophe. Wiesbaden: Springer VS.

Schwarz, S. (2014b). The social dimension of coping: Communal negotiations of social benefits and burdens. In M. Zaumseil; S. Schwarz.; M. von Vacano; G. Sullivan.; J. Prawitasari-Hadiyono (Eds.). Cultural psychology of coping with disasters. The case of an earthquake in Java, Indonesia (pp.203-223). New York: Springer.

Schwarz, S. (2014c). Disaster aid distribution and social conflicts. In M. Zaumseil; S. Schwarz.; M. von Vacano; G. Sullivan.; J. Prawitasari-Hadiyono (Eds.). Cultural psychology of coping with disasters. The case of an earthquake in Java, Indonesia (pp. 285-301). New York: Springer.

Schweizer, T. (1989). Economic individualism and the community spirit: Divergent orientation patterns of Javanese villagers in rice production and the ritual sphere. Modern Asian Studies, 23(2), pp. 277-312. http://dx.doi.org/10.1017/S0026749X00001074

Sidanius, J.; Pratto, F. (1999). Social dominance: An intergroup theory of social hierarchy and oppression. New York: Cambridge University Press. http://dx.doi.org/10.1017/CBO9781139175043

Sidanius, J.; Pratto, F.; van Laar, C.; Levin, S. (2004). Social dominance theory: It's agenda and method. Political Psychology, 25 (6), pp. 845-880. http://dx.doi.org/10.1111/j.1467-9221.2004.00401.x

Subagyo, B., \& Irawan, V. (2008). Building local governments and communities that are more resilient to hazards. In D. Karnawati (Ed.), The Yogyakarta earthquake of May 27, 2006 (pp. 23.1-23.8). Belmont: Star Publishing Company.

United Nations (UN). (2000). Report of the Ad Hoc Committee of the Whole of the twenty-third special session of the General Assembly. General Assembly. Official Records. Twenty-third special session. Supplement Nr. 3. A/S-23/10/Rev.1. New York. http://www.un.org/womenwatch/daw/followup/as2310rev1.pdf. Accessed 29.03.2013.

United Nations / International Strategy for Disaster Reduction (UN/ISDR). (2007). Gender perspective: Working together for disaster risk reduction. Good practices and lessons learned. Geneva. http://www.unisdr.org/files/547_gendergoodpractices.pdf. Accessed 24.03.2014.

WHO 2007 http://www.who.int/hac/techguidance/tools/manuals/who_field_handbook/annex_7/en/index.html. Accessed 8 May 2013.

Wichterich, C. (2010). Gender als politisches Projekt: Wie bitte geht's zur Geschlechtergerechtigkeit? Berlin: Friedrich-Ebert-Stiftung. http://library.fes.de/pdf-files/iez/07025.pdf. Accessed 24 July 2012.

Wilson, P. \& Reilly, D. (2007). Report CARE, Catholic Relief Services, Save the Children and World Vision Indonesia. Joint evaluation of their responses to the Yogyakarta earthquake. http://www.crsprogramquality.org/storage/pubs/me/yogyakarta.pdf Accessed 18 June 2013. 
Wolf, D. (1992). Factory daughters. Gender, household dynamics, and rural industrialization in Java. Berkeley: University of California Press.

Yonder, A., Akcar, S., \& Gopalan, P. (2006). Women's participation in disaster relief and recovery. New York: The Population Council.

\section{Notes}

Note 1. The terms Global North and Global South encompass social, cultural, political and economic dimensions of difference on a global scale. In economic terms, the Global North is richer and more developed; it is technologically advanced and politically stable. Generally, definitions of the Global North include countries which are mainly in western Europe, North America, and developed parts of East Asia, and the South encompasses poorer countries of Africa, Asia, the Middle East, and Central and South America.

Note 2. http://www.dawnnet.org/index.php. Accessed 29.03.2014. http://www.duryognivaran.org/. Accessed 29.03.2014.

Note 3 . The name of the research site was changed to ensure anonymity.

Note 4. For a detailed description of the sample as well as of data collection and analysis methods see Schwarz 2014a.

Note 5. Translation from German by Sarah Howard. 